\title{
Dust Interception Capacity And Alteration Of Various Biometric And Biochemical Attributes In Cultivated Population Of Ficus Carica L.
}

\author{
Uzma Younis, Tasveer Zahra Bokhari, Muhammad Hasnain Raza Shah, \\ Seema Mahmood and Saeed Ahmad Malik \\ Institute of Pure and Applied Biology, Botany department, Bahauddin Zakariya University, Multan, Pakistan
}

\begin{abstract}
The dust accumulation capacity of Ficus carica $L$. was evaluated from eight different sites in and around Multan. The impact of dust accumulation was observed via various biometric attributes (leaf area, leaf fresh and dry weights) and biochemical attributes (chlorophyll contents, carotenoids \& ascorbic acid) from leaves of F. carica. The maximum dust accumulation was occurred in the plants growing at Road sides while, the minimum dust was found on plants growing at Bahauddin Zakariya University. Dust accumulation has caused a significant effect on almost all foliage and biochemical attributes of F. carica.

A positive correlation was found between dust accumulation and biometric attributes in $F$. carica. Biochemical responses had shown an inconsistency as chlorophylls ( $a, b \&$ total), carotenoids decreased and ascorbic acid contents increased with an increase in dust accumulation. A negative correlation was found between dust deposition and chlorophyll contents. Whereas, accumulation of ascorbic acid was associated with a decline in pigment contents.
\end{abstract}

Key Words: Dust interception, Ficus carica, biometric and biochemical attributes.

\section{Introduction}

Dust is a general name for solid particles having diameters $>500 \mu \mathrm{m}$ but particles of $2.5-10 \mu \mathrm{m}$ in atmospheric are of great concern for health of local public (Borja-Aburto et al., 1998; Beckett et al., 1998). Dust particles arise from natural sources such as soil dust lifted up by wind and volcanic eruptions but sometimes dust also contains small amounts of pollen grains, human and animal hairs, stuff and paper fibers and many other materials (Kathleen Hess-Kosa, 2002). Windblown dust is a common feature of arid ecosystems as soils remain dry and serve as a major source of small particulate matter (Sharifi et al., 1997). In addition, agricultural activities and fast moving traffic also generate high dust concentrations (Leys et al., 1998; Manins et al., 2001).

Considerable attention is given to particulate matter pollution in the recent years because it caused severe health harms (Jafary et al., 2007). Worldwide particularly in urban areas almost 600 million persons suffered from a variety of ailments due to dust pollution (Cacciola et al., 2002).

Accumulation and deposition of gaseous pollutants and particulate matter depends upon the vegetation type (Bunzl et al., 1989; Fowler et al., 1989). Vegetation makes contribution in reducing dust concentration in environment by acting as a sink for air pollutants. Due to surface characteristics of twigs, bark and foliage of the plants particulate matters are captured by them and remain there for extended time period. Generally exposed areas of a plant especially leaves act as constant absorbers for particulate matters (Samal and Santra, 2002). Thus air quality in urban/ arid areas can be improved by planting trees along road sides and agricultural lands (Beckett, et al., 2000; Freer-Smith et al., 2005; Raupach et al., 2001). However, dust accumulation capability of plants depends on their range of characteristics which include outside geometry, phyllotaxy and leaf attributes (cuticle and pubescence of leaves), tallness and canopy of plants.

On the other hand, morphology and internal structure of leaves is altered by heavy load of dust pollutants (Somashekar et al., 1999; Gostin, 2009; Sukumaran, 2012). Particulate pollutants can cause many lethal effects on plants like stomatal clogging, reduced photosynthetic activity, leaf fall and death of tissues (Singh and Sthapak, 1999; Farooq et al., 2000; Shrivastava and Joshi, 2002; Garg et al., 2000). Leaf chlorosis also caused by dust pollution due to its effect on chlorophyll biosynthesis (Seyyednejad et al., 2011). However, many plant types are able to stable their populations despite significant dust fall/deposition on their exposed surfaces because harmful effects of particulate matter are scavenged by carotenoids and ascorbic acid production which are the expression of non-enzymatic resistance in plants to numerous abiotic stresses (Prajapati and Tripathi, 2008).

Multan (Plate-I) is the third largest city of the province Punjab, Pakistan. The city is famous for dust storm. Urbanization of the city particularly during the last decade had resulted in deforestation and significant increase in the number of automobiles has aggravated the problem of particulate matter pollution. 
Keeping in view the above situation, the present study aimed to evaluate possible role of local vegetation to control particulate mater pollution. Dust accumulation capacity of cultivated populations of Ficus carica from spatially and temporally diverse habitats was studied. Alteration of various traits was studied to assess the impact of dust accumulation on a tree species. Changes in the two important non enzymatic components; carotenoids and ascorbic acid were studied to suggest their possible role in scavenging adverse effects of dust.

Plate-I: Map showing study site i.e. Multan city.

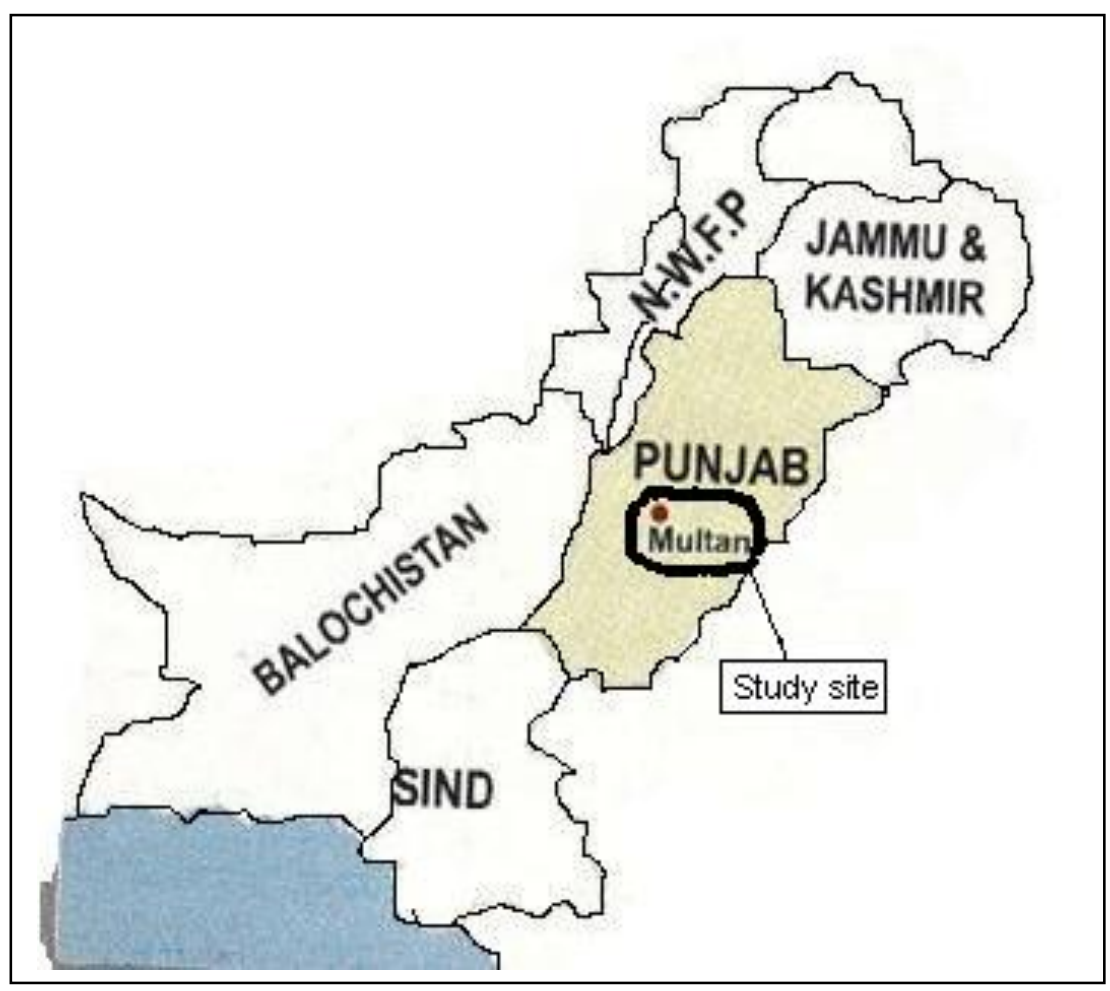

\section{Materials And Methods}

Study material and Study area selection

The plant species Ficus carica was selected for study because population of this species was present in diverse habitats which were exposed to dust pollution both spatially and temporally. Ease of sampling due to small sized trees (3-10m tall) and foliage characteristics (broad, oblong elliptic leaves with long petiole) made the species a feasible material.

Eight main areas of Multan city (Plate I) were selected for sampling of plant material from cultivated population of the species. Multan region was selected for this study because it is the third largest city of the Punjab province in Pakistan. These sites were selected on the basis of traffic density, dust concentration, urbanization and industrialization. The sampling was carried out during May-June, 2011 because during these months weather remains dry and the frequency of incidence of dust storm, which is typical to the city, is greater. The detail of these areas is summarized in Table 1 and city is marked on the map (Plate I).

Table 1: Study sites with dust pollution sources.

\begin{tabular}{|c|l|l|}
\hline $\begin{array}{c}\text { Site/ } \\
\text { Population }\end{array}$ & \multicolumn{1}{|c|}{ Area } & \multicolumn{1}{c|}{ Source of particulate matter pollution } \\
\hline I & Bahauddin Zakariya University & Dust storm, wind erosion \\
\hline II & Bosan Road & Busy road sides, fast moving automobiles/vehicles \\
\hline III & Cricket stadium & Barren land, dust storm, wind erosion \\
\hline IV & Cultivated wheat field & Plugging and Thrashing \\
\hline V & Industrial Estate & Cement, Ceramic, and pesticides industries \\
\hline VI & Multan Railway station & $\begin{array}{l}\text { Barren land and fast moving trains, smoke from } \\
\text { diesel of locomotives }\end{array}$ \\
\hline VII & Pak Arab Fertilizers & Barren land, factory exhaust, heavy loaded trucks \\
\hline VIII & Public parks & Wind blown dust and sand from trampled park areas \\
\hline
\end{tabular}




\section{Sampling Protocols for Dust and Leaves}

Tress of $F$. carica species were selected at each sampling site and 20 leaves were randomly marked on each tree at 2-3 $\mathrm{m}$ height. The leaves were carefully removed from the branches and were wrapped in pre-weighed glazed papers then put in polythene bags and brought back to the laboratory. The wrapped leaves were carefully taken out from the bags, glazed paper was spread in a glass chamber and dust present on the leaves was cleaned using a fine brush. All the dust was collected on the glazed papers. They were reweighed and the amount of dust collected from each leaf was recorded. Leaf area $\left(\mathrm{cm}^{2}\right)$ measurements were taken using leaf area meter (DeltaT-Device area meter) and capacity of dust accumulation was calculated following Prajapati and Tripathi (2008) as under:

$$
\mathrm{W}=(\mathrm{w} 2-\mathrm{w} 1) / \mathrm{a}
$$

Where $W$ is dust content $\left(\mathrm{g} \mathrm{m}^{-2}\right)$, w1 is initial weight of glazed paper, w2 is final weight of glazed paper with dust, and " $a$ " is total area of the leaf $\left(\mathrm{m}^{2}\right)$.

The leaves samples were then used for various biometric and biochemical parameters. Fresh weights were taken and leaf material was oven dried at $70^{\circ} \mathrm{C}$ for $72 \mathrm{~h}$ for dry weight measurements using a digital balance (AC 220V, Tokyo, Japan)

\section{Chlorophyll determination}

Chlorophyll and carotenoids were extracted in $80 \%$ acetone from leaves and the amount of chlorophyll $a, b$, and total, were quantified spectrophotometrically (UV-1900 Japan) following Arnon (1949).

Chlorophyll a $(\mathrm{mg} / \mathrm{g} \mathrm{F.W})=\frac{12.7(\mathrm{OD} 663)-2.69(\mathrm{OD} 645) \mathrm{V}}{1000(\mathrm{~W})}$

Chlorophyll b $(\mathrm{mg} / \mathrm{g}$ F.W $)=\frac{22.9(\mathrm{OD} 645)-4.68(\mathrm{OD} 663) \mathrm{V}}{1000(\mathrm{~W})}$

Total chlorophyll $(\mathrm{mg} / \mathrm{g}$ F.W $)=\frac{20.2(\mathrm{OD} 645)+8.02(\mathrm{OD} 663) \mathrm{V}}{1000(\mathrm{~W})}$

The carotenoids were calculated by the following formulae given by Krik and Allen (1965).

$$
\text { Carotenoids }(\mathrm{mg} / \mathrm{g} \text { F.W })=\text { OD } 480+0.114(\text { OD 663) }-0.638(\text { OD 645) }
$$

\section{Ascorbic Acid}

For ascorbic acid determination $5 \mathrm{~g}$ of fresh leaf was homogenized in $20 \mathrm{ml}$ extracting solution $(0.75 \mathrm{~g}$ sodium salt of EDTA and $5 \mathrm{~g}$ oxalic acid dissolved in $100 \mathrm{ml}$ distilled water). Homogenized leaf material was centrifuged for fifteen minutes at $628.2 \mathrm{rads}^{-1}$. Then $1 \mathrm{ml}$ of homogenate was mixed with $5 \mathrm{ml}$ Dichlorophenol indophenol (DCPIP) $\left(0.02 \mathrm{~g} \mathrm{~L}^{-1}\right)$ with regular shaking. With the aid of a spectrophotometer Optical density of pink colored solution was determined at $520 \mathrm{~nm}$ (Es). After this solution was decolorize by adding one drop of $1 \%$ ascorbic acid, then optical density of turbid solution (Et) was determined at the same wave length. A calibration curve was plotted using ascorbic acid standard (Camlab U.K.). Keller and Schwager (1977) were followed to calculate Ascorbic acid content. The formula is as follows:

$$
\text { Ascorbic Acid (mg/g F.W) }=\frac{\text { (Eo-Es-Et) V }}{100 \mathrm{~W}} .100
$$

where, $E_{\mathrm{o}}, E_{\mathrm{s}}$, and $E_{\mathrm{t}}$ are optical densities of blank sample, plant sample, and sample with ascorbic acid, respectively, $V=$ volume of extract, and $W=$ leaf sample weight $(\mathrm{g})$.

\section{Results}

Dust accumulation on the leaves of F. carica from different sites is presented in Figure 1 (A). It is evident from the Figure that the species had differential dust deposition with respect to various sampling sites. The maximum accumulation or deposition of dust was observer for Ficus carica from Bosan Road. By contrast, the minimum amount of dust was collected from the leaves of the species from the university which was an inland location. The dust load among sites was variable, however, the trend of dust deposition was Bosan Road $>$ Park Arab Fertilizer > Parks > Multan Railway Station >Industrial Estate>Cultivated wheat filed $>$ Cricket Stadium>Bahauddin Zakariya University.

Analysis of variance of the data for dust accumulation is presented in Table 2, depicted that the amount of dust from various sites varied significantly $(\mathrm{P}<0.001)$. A significantly profound dust load was observed from Bosan Road however, it did not differ markedly from the other two sites that is railway station and public parks. 
Though, the lowest amount of dust was collected from the university but it did not show any significant contrast from stadium and cultivated wheat fields. Similarly, dust load from fertilizer factory and industrial estate was significantly invariable. Though, sampling sites possessed a significant contrast with respect to dust deposition but the amount of dust load was comparable from sites which have similar sources/ origin of dust.

Leaf area of $F$. carica plant is presented in Figure 1 (B). It is evident from the Figure that plants grown at Bahauddin Zakariya University site had the minimum area $\left(69.35 \mathrm{~cm}^{2}\right)$ of the leaf and the maximum leaf area $\left(146.48 \mathrm{~cm}^{2}\right)$ was observed from the plants collected from Bosan road site. Though leaf area among sites was significantly $(\mathrm{P}<0.001)$ variable but only Bahauddin Zakariya University site has shown a significant contrast form all other sites. No significant variability was observed for the Bosan road, Industrial estate, Pak Arab fertilizers, Public parks and Railway station sites. However, all these sites possessed a significant contrast from Bahauddin Zakariya University, Cricket stadium and cultivated wheat field sites. While, the later two sites did not differ significantly for this attribute.
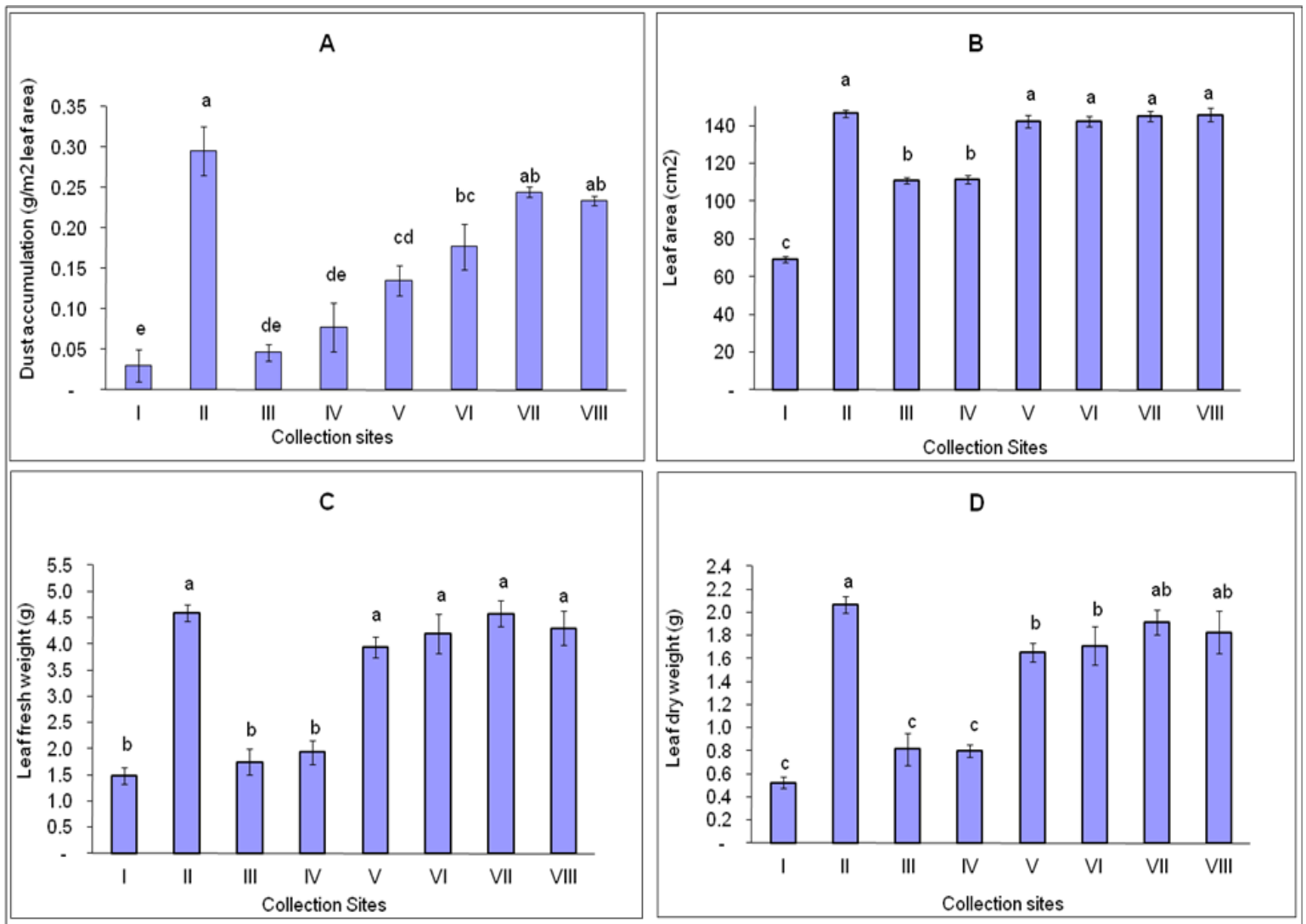

Figure 1. A. Dust accumulation, B. Leaf area, C. Leaf fresh weight, D. Leaf dry weight of $F$. carica collected from different sites of Multan, Pakistan. Values are means of ten replicates. Values designated over the bars sharing same letters are not significantly different at $\mathrm{P}<0.001$ level by Duncan's Multiple Range Test.

The data presented in Figure 1 (C) for leaves fresh weight showed differential fresh weight of the species from different sites. The fresh weight of $F$. carica ranged from $1.49 \mathrm{~g}$ to $4.58 \mathrm{~g}$. The minimum $(1.49 \mathrm{~g})$ fresh weight was recorded from the Bahauddin Zakariya University site and the maximum (4.58g) fresh weight was recorded form Bosan Road site.

Analysis of variance (Table-2) depicted a significant $(\mathrm{P}<0.001)$ contrast among sites. However, leaf fresh weight was significantly lower $(1.49 \mathrm{~g}-1.93 \mathrm{~g})$ for Bahauddin Zakariya University, cricket stadium and cultivated wheat field and these sites did not show any marked contrast among them for leaf fresh weight. Similarly other sites also showed similar fresh weight of leaves and did not differ significantly from one another.

Leaf dry weight also exhibited a similar trend. The lowest $(0.52 \mathrm{~g})$ dry weight of leaf was observed from Bahauddin Zakariya University site while the highest $(2.06 \mathrm{~g})$ from Bosan road site. (Figure 1, D)

It is evident from the Figure 2 (A) that chlorophyll contents of the species varied with respect to different sites. The highest (1.40mg/g F.W) amount of chlorophyll $a$ was recorded from the plants of Bahauddin Zakariya University site and the lowest $(0.79 \mathrm{mg} / \mathrm{g} \mathrm{F.W})$ from Bosan road site. Although, other sites also have variable 
chlorophyll a contents. No significant $(\mathrm{P}<0.001)$ differences were observed for chlorophyll $a$ from all the sites expects Bahauddin Zakariya University and Bosan road sites.

Significantly lower amount $(0.37 \mathrm{mg} / \mathrm{g} \mathrm{F.W})$ of chlorophyll $b$ was observed from Bosan road site but it did not show any significant variability from Pak Arab fertilizers, Public parks and Railway station sites. Similarly, cultivated wheat field and Industrial estate were also significantly $(\mathrm{P}<0.001)$ variable for chlorophyll $b$ contents. The higher amount $(1.05 \mathrm{mg} / \mathrm{g} \mathrm{F.W})$ of chlorophyll $b$ was found from the Bahauddin Zakariya University and Cricket stadium sites respectively. But these sites did not differ significantly for chlorophyll $b$ contents.

The total chlorophyll contents were higher $(2.43-2.38 \mathrm{mg} / \mathrm{g} \mathrm{F.W})$ in plants collected from Bahauddin Zakariya University and Cricket stadium sites and differ remarkably from all other sites. There were also present significant $(\mathrm{P}<0.001)$ difference among other sites but Cultivated wheat field, Industrial estate, Pak Arab fertilizers, Public parks and Railway station sites did not show any variability among them.

The responses of species for carotenoids contents were significantly $(\mathrm{P}<0.001)$ variable for different sites. However, Pak Arab fertilizers, Public parks and Railway station sites have significantly invariable carotenoids contents. Similarly, higher $(1.75 \mathrm{mg} / \mathrm{g} \mathrm{F}$.W) carotenoids contents were found in the leaves of the species from Bahauddin Zakariya University and cricket stadium sites but did not varied markedly between them. Similarly, cultivated wheat field and Industrial estate did not show any significant disparity for carotenoids contents, though, they have different carotenoids contents. While, the lowest $(0.74 \mathrm{mg} / \mathrm{g} \mathrm{F.W})$ carotenoids contents were observed from the plants collected from Bosan road site. (Figure 2, B)

The minimum amount $(0.18 \mathrm{mg} / \mathrm{g}$ F.W $)$ of ascorbic contents was observed for Bahauddin Zakariya University site and the maximum $(0.62 \mathrm{mg} / \mathrm{g} \mathrm{F.W})$ ascorbic acid contents were recorded from Bosan road site. However, the ascorbic acid contents from cricket stadium, cultivated wheat field, Industrial estate and Pak Arab fertilizers were lower as compared with other sites. Among all these sites only Bahauddin Zakariya University and Bosan road sites exhibited a significant $(\mathrm{P}<0.001)$ contrast from all other sites. Likewise, cricket stadium, cultivated wheat field, Industrial estate and Pak Arab fertilizers also shown similar responses for ascorbic acid contents and no significant differences were present among these sites. (Figure 2, B)

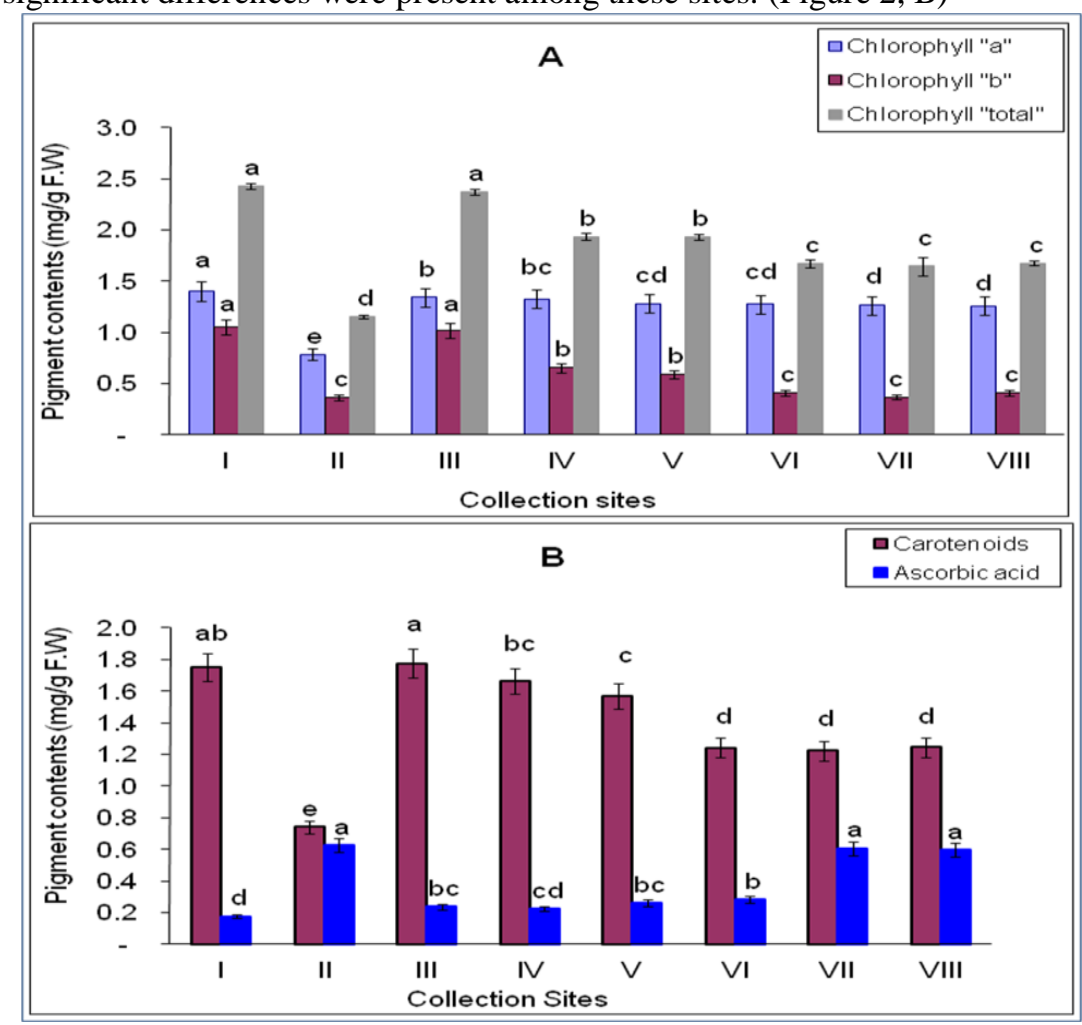

Figure 2. A. Chlorophyll (a, b \& total) contents, B. Ascorbic acid and Carotenoids contents of $F$. carica collected from different sites of Multan, Pakistan. Values are means of five replicates. Values designated over the bars sharing same letters are not significantly different at $\mathrm{P}<0.001$ level by Duncan's Multiple Range Test.

The present study showed that biometric attributes (leaf area, leaf fresh and dry weight) and ascorbic acid contents of $F$. carica increased with increasing dust accumulation, whereas, chlorophyll and carotenoids contents showed opposite trend. The Pearson correlation coefficient values of dust accumulation with biometric and biochemical attributes in F. carica are presented in Table 3. From the Table it is cleared that dust 
accumulation has highly significant positive correlation with biometric attributes and ascorbic acid contents but has highly significant negative correlation with chlorophyll and carotenoids contents.

Table 2: Analysis of Variance of Dust accumulation, biometric and biochemical attributes of $F$. carica collected from different sites of Multan, Pakistan

\begin{tabular}{|c|c|c|c|c|c|}
\hline \multicolumn{6}{|c|}{ Dust accumulation } \\
\hline Source & Df & SS & MS & $\mathbf{F}$ & LSD \\
\hline Sites & 7 & 0.68 & 0.097 & $9.48^{\star \star *}$ & 0.09 \\
\hline Error & 72 & 0.741 & 0.01 & & \\
\hline Total & 79 & 1.422 & & & \\
\hline \multicolumn{6}{|c|}{ Biometric and biochemical attributes ANOVA } \\
\hline \multicolumn{6}{|c|}{ Leaf fresh weight } \\
\hline Source & Df & SS & MS & $\mathbf{F}$ & LSD \\
\hline Sites & 7 & 130.5 & 18.64 & $29.95^{\star * *}$ & 0.703 \\
\hline Error & 72 & 44.81 & 0.622 & & \\
\hline Total & 79 & 79.18 & & & \\
\hline \multicolumn{6}{|c|}{ Leaf dry weight } \\
\hline Sites & 7 & 25.26 & 3.61 & $26.41^{* * *}$ & 0.329 \\
\hline Error & 72 & 9.83 & 0.137 & & \\
\hline Total & 79 & 35.1 & & & \\
\hline \multicolumn{6}{|c|}{ Leaf area } \\
\hline Sites & 7 & 53391.5 & 7627.3 & $10.94^{\star \star *}$ & 23.5427 \\
\hline Error & 72 & 50211.4 & 697.4 & & \\
\hline Total & 79 & 103602.86 & & & \\
\hline \multicolumn{6}{|c|}{ Chlorophyll "a" } \\
\hline Sites & 7 & 1.276 & 0.182 & $92.24^{* * *}$ & 0.0572 \\
\hline Error & 32 & 0.06 & 0.002 & & \\
\hline Total & 39 & 1.339 & & & \\
\hline \multicolumn{6}{|c|}{ Chlorophyll "b" } \\
\hline Sites & 7 & 2.814 & 0.4 & $39.55^{\star \star *}$ & 0.12988 \\
\hline Error & 32 & 0.325 & 0.01 & & \\
\hline Total & 39 & 3.139 & & & \\
\hline \multicolumn{6}{|c|}{ Chlorophyll "total" } \\
\hline Sites & 7 & 6.07 & 0.87 & $92.59^{* * *}$ & 0.1247 \\
\hline Error & 32 & 0.299 & 0.009 & & \\
\hline Total & 39 & 6.37 & & & \\
\hline \multicolumn{6}{|c|}{ Carotenoids } \\
\hline Sites & 7 & 4.38 & 0.626 & $97.04^{* * *}$ & 0.10347 \\
\hline Error & 32 & 0.21 & 0.006 & & \\
\hline Total & 39 & 4.589 & & & \\
\hline \multicolumn{6}{|c|}{ Ascorbic Acid } \\
\hline Sites & 7 & 1.331 & 0.19 & $130.22^{* * *}$ & 0.049 \\
\hline Error & 32 & 0.047 & 0.001 & & \\
\hline Total & 39 & 1.378 & & & \\
\hline
\end{tabular}


Table 3: Correlation of dust accumulation with biometric and biochemical attributes of $F$. carica collected from different sites of Multan, Pakistan.

\begin{tabular}{|l|r|}
\hline \multicolumn{1}{|c|}{ Foliage and biochemical attributes } & \multicolumn{1}{c|}{ Ficus carica } \\
\hline Leaf Area & 0.528 \\
\hline Fresh weight & 0.455 \\
\hline Dry weight & 0.455 \\
\hline Chlorophyll a & -0.729 \\
\hline Chlorophyll b & -0.765 \\
\hline Total chlorophyll & -0.905 \\
\hline Carotenoids & -0.065 \\
\hline Ascorbic acid & 0.924 \\
\hline
\end{tabular}

\section{Discussion}

The present study shows significant variation in dust accumulation in Ficus carica at different sites in and around Multan. Variety of factors, such as leaf uniqueness i.e. form and size, orientation, surface texture, occurrence/lack of leaf hairs, petioles length etc., air current and its speed, climatic conditions and anthropogenic actions effect the dust interception/accumulation capacity of different plants.

. In addition, degree of pubescence and large surface area allow the species to capture more dust particles which is an important manifestation of particulate pollution. The influence of foliage characteristics on dust accumulation has also been studied by many workers (Vora and Bhatnagar, 1986; Somashekar et al., 1999). Morphological attributes such as cuticular waxes, raised epidermal cell margins, trichomes, ledges of stomata and epicuticular lignin and waxes give roughness to leaves (Pal et al., 2002). More dust accumulation in plants growing at road sides may be due to high dust intensity which results by the vehicles activity and capturing dust, with a gentle wind. In the plants at B.Z.University area there is minimum dust accumulation due to more plantations and less bare land. Thus, F. carica can one of the important contributors for cleaning up dust pollution from the environment.

Farmer (1993) stated that sufficient quantities of dust particles may form a smother layer on foliage, reduced light capturing ability of plants, hence lower the photosynthetic rates, clogged stomata, increased foliage temperature, effect fruit set, leaf development, pollen growth, reduced plant growth, caused chlorosis and necrosis of leaf, bark peeling and the same results were observed in the present study that dust accumulation had significant effect on leaf area of $F$. carica because there was positive correlation between dust accumulation and leaf area of $F$. carica.

Development and growth of plants are controlled by number of ecological factors such as soil, water and air (Katiyar and Dubey, 2000). Variation in leaf pigments (chlorophyll a, b, total, carotenoids and ascorbic acid) are may be caused by these factors. Dust particles carry many polycyclic hydrocarbon and metals with them which inhibits the production of enzymes required for chlorophyll formation and results in reduction of chlorophyll molecules with increasing dust accumulation on plants (Prajapati and Tripathi, 2008). Dust pollution puts pressure on plants by affecting availability of light for photosynthesis and diffusion of air is affected by blocking stomatal pore (Hope et al., 1991; Keller and Lamprecht, 1995; Anthony, 2001). From the present study it is cleared that both chlorophyll ( $\mathrm{a}, \mathrm{b}$, total) and ascorbic acid content showed different responses to dust accumulation. Dust accumulation caused alkalinity in leaves by chemicals dissolution of dust particles in cell sap which results in chlorophyll damaged. To accommodate these stresses leaves ascorbic acid contents increased which decreased the leaf senescence (Garg and Kapoor, 1972). Several scientists demonstrated that chlorophyll content of dust polluted leaves is lower than that of control leaves (Somashekar et al., 1999; Mandal and Mukherji, 2000; Samal and Santra, 2002). F. carica owing to its long petioles and broadly ovate leaves had shown the maximum dust accumulation capacity along road sides. In addition, degree of pubescence and large surface area allow the species to capture more dust particles which is an important manifestation of particulate pollution. Thus, $F$. carica can one of the important contributors for cleaning up dust pollution from the environment. The study clearly suggested that plantation of $F$. carica in dusty areas can control particulate pollution which may cause hazardous consequences for human health. The study clearly suggested that plantation of $F$. carica in dusty areas can control particulate pollution which may cause hazardous consequences for human health. 


\section{References}

[1]. Anthony P (2001). Dust from walking tracks: Impacts on rainforest leaves and epiphylls. Cooperative Research Centre for Tropical Rainforest Ecology and Management, Australia.

[2]. Arnon D (1949). Plant Physiology. 24, 1 - 15.

[3]. Beckett KP, Freer-Smith PH, Taylor G (1998). Urban woodlands: Their role in reducing the effects of particulate pollution. Environ. Pollut.99, 347-360.

[4]. Beckett KP, Freer-Smith PH, Taylor G (2000). Particulate pollution capture by urban trees: Effect of species and windspeed. Glob. Change Biol. 6, 995-1003.

[5]. Borja-Aburto VH, Castillejos M, Gold DR, Bierzwinski S, Loomis D (1998). Mortality and ambient fine particles in southwest Mexico city, 1993-1995. Environ. Health Perspect. 106, 849-855.

[6]. Bunzl K, Schimmack W, Kreutzer K, Schierl R (1989). Interception and retention of Chernobyl-derived ${ }^{134,137}$ Cs and ${ }^{100}$ Ru in a spruce stand. Sci. Total Environ. 78, 77-87.

[7]. Cacciola RR, Sarva M, Polosa R (2002). Adverse respiratory effects and allergic susceptibility in relation to particulate air pollution: Flirting with disaster. Allergy. 57, 281-286.

[8]. Farmer AM (1993). The effects of dusts on vegetation- A review. Environ. Pollut. 79, 63-75.

[9]. Farooq M, Arya KR, Kumar S, Gopal K, Joshi PC, Hans RK (2000). Industrial pollutants mediated damage to mango (Mangifera Indica) crop: A case study. J. Environ. Biol. 21, 165-167.

[10]. Fowler D, Cape JN, Unsworth MH (1989). Deposition of atmospheric pollutants on forests. Philos. Trans. R. Soc. London. 324, $247-265$.

[11]. Freer-Smith PH, Beckett KP, Taylor G (2005). Deposition velocities to Sorbus aria, Acer campestre, Populus deltoides $x$ trichocarpa 'Beaupre', Pinus nigra and $x$ Cupressocyparis leylandii for coarse, fine and ultra-fine particles in the urban environment. Environ. Pollut. 133, 157-167.

[12]. Garg OP, Kapoor V (1972). Retardation of leaf senescence by ascorbic acid. J. Exp. Bot. 23, 699-703.

[13]. Garg SS, Kumar N, Das G (2000). Ind. J. Environ. Prot. 20, 326-328.

[14]. Gostin IN (2009). Air Pollution Effects on the Leaf Structure of some Fabaceae Species. Not. Bot. Hort. Agrobot. Cluj. 37, 57-63

[15]. Hope AS, Fleming JB, Stow DA, Aguado E (1991). Tussock tundra albedos on the north slope of Alaska: Effects of illumination, vegetation composition, and dust deposition. J. Appl. Meteorol. 30, 1200-1206.

[16]. Jafary ZA, Faridi IA, Qureshi HJ (2007). Effects of airborne dust on lung function of the exposed subjects. Pak J Physiol. 3, $30-34$.

[17]. Joshi N, Chauhan A, Joshi PC (2009). Impact of industrial pollutants on some biochemical parameters and yield in wheat and mustard plants. Environmentalist. 29, 398-404.

[18]. Kathleen Hess-Kosa (2002), Indoor Air Quality: sampling methodologies, page 216. CRC Press.

[19]. Katiyar V, Dubey PS (2000). Growth behaviour of two cultivars of maize in response to $\mathrm{SO}_{2}$ and $\mathrm{NO}_{2}$. J. Environ. Biol. 21, 317323.

[20]. Keller J, Lamprecht R (1995). Road dust as an indicator for air pollution transport and deposition: An application of SPOT imagery. Remote Sens. Environ. 54, 1-12.

[21]. Keller T, Schwager H (1977). Air pollution and ascorbic acid. Eur. J. For. Pathol. 7, 338-350.

[22]. Krik JTO, Allen RL (1965). Dependence of chloroplast pigment synthesis on protein synthesis: Effect of actidione. Biochemical Biophysical Research communications. 21, 523-530.

[23]. Leys JF, Larney FJ, Muller JF, Raupach MR, McTainsh GH, Lynch AW (1998). Anthropogenic dust and endosulfan emissions on a cotton farm in northern New South Wales, Australia. Sci. Total Environ. 220, 55-70.

[24]. Mandal M, Mukherji S (2000). Changes in chlorophyll context, chlorophyllase activity, Hill reaction, photosynthetic $\mathrm{CO}_{2}$ uptake, sugar and starch contents in five dicotyledonous plants exposed to automobile exhaust pollution. J. Environ. Biol. $21,37-41$.

[25]. Manins P, Allan R, Beer T, Fraser P, Holper P, Suppiah R, Walsh K (2001). Atmosphere. Australia State of the Environment Rep. 2001 (Theme Rep.). CSIRO Publ., Melbourne.

[26]. Pal A, Kulshreshtha K, Ahmad KJ, Behl HM (2002). Do leaf surface characters play a role in plant resistance to auto exhaust pollution. Flora 197, 47-55.

[27]. Prajapati SK, Tripathi BD (2008). Seasonal Variation of Leaf Dust Exposed to Urban Particulates Pollution. J Environ Qual. 37, 865-870

Accumulation and Pigment Content in Plant Species

[28]. Raupach MR, Woods N, Dorr G, Leys JF, Cleugh HA (2001). The entrapment of particles by windbreaks. Atmos. Environ. 35, 3373-3383.

[29]. Samal AK, Santra SC (2002). Ind. J. Environ. Health 44, 71-76.

[30]. Seyyednejad SM, Niknejad M, Koochak H (2011). A review of some different effects of air pollution on plants. Res. J. Environ. Sci. 5, 302-309.

[31]. Sharifi MR, Gibson AC, Rundel PW (1997). Surface dust impacts on gas exchange in Mojave Desert shrubs, Journal of Applied Ecology. 34, 837-846.

[32]. Shrivastava N, Joshi S (2002). Effect of automobile air pollution on the growth of some plants at Kota. Geobios 29, $281-282$.

[33]. Singh P, Sthapak J (1999). Reduction in protein contents in a few plants as indicators of air pollution. Pollut. Res. 18, 281-283.

[34]. Somashekar RK, Ravikumar R, Ramesh AM (1999). Pollut. Res. 18, 445-451.

[35]. Sukumaran D (2012). Effect of Particulate Pollution on various Tissue Systems of Tropical Plants. Central Pollution Control Board (CPCB), Zonal Office, Kolkata, India.

[36]. Vora AB, Bhatnagar AR (1986). Comparative study of dust fall on the leaves in high pollution and low pollution areas of Ahmedabad. J. Environ. Biol. 7, 155-163. 